\title{
Structural Investigation for Locating Petroleum Reservoirs Using Geoinformatics in Meyal, Potwar Region, Pakistan
}

\author{
Zohaib Fayyaz $^{1}$, Dr. Javed Iqbal ${ }^{1}$, Ahsan Mehboob ${ }^{1}$, Muhammad Affan Sabir ${ }^{2}$, Abdul Jabbar ${ }^{3}$ \\ ${ }^{1}$ Institute of Geographical Information System, School of Civil and Environmental Engineering, National University of Sciences and \\ Technology (NUST), Islamabad, Pakistan \\ ${ }^{2}$ Institute of Geology, University of the Punjab, Lahore, Pakistan \\ ${ }^{3}$ NUST Institute of Civil Engineering, National University of Sciences and Technology, Islamabad, Pakistan \\ Email: Fayyaz.zohaib@gmail.com
}

How to cite this paper: Fayyaz, Z., Iqbal, Dr.J., Mehboob, A., Sabir, M.A. and Jabbar, A. (2016) Structural Investigation for Locating Petroleum Reservoirs Using Geoinformatics in Meyal, Potwar Region, Pakistan. International Journal of Geosciences, 7, 1345-1355.

http://dx.doi.org/10.4236/ijg.2016.711098

Received: September 10, 2016

Accepted: November 27, 2016

Published: November 30, 2016

Copyright (c) 2016 by authors and Scientific Research Publishing Inc. This work is licensed under the Creative Commons Attribution International License (CC BY 4.0).

http://creativecommons.org/licenses/by/4.0/

\begin{abstract}
Reflection Seismology technique (Seismic Survey) is widely used around the world to produce a detailed analogue image of subsurface geological structures. This information is used by petroleum experts to accurately plan the location of oil wells. Seismic survey sections and corresponding well logs exhibit different variables like acoustic impedance of rock, seismic velocity, rock density, porosity, time and depth that can be manipulated in GIS to infer a subsurface model for stratigraphic as well as structural interpretations. In recent years, GIS has emerged as a powerful analytical tool for subsurface mapping and analysis. Petroleum exploration is a map intensive process that requires the powerful capabilities of GIS. Purpose of this research is integration of Geographical Information System with Seismic Surveys for Structural and Stratigraphic Interpretation of subsurface Geology and locating Petroleum Prospects. In this research work, GIS has been used to investigate subsurface geological structures and stratigraphy to carefully analyze the capabilities of GIS for finding new petroleum prospects in active thrust belt of Meyal, Potwar region, Pakistan. Acquisition of two-dip and three-strike seismic lines is along with well log data, followed by spatial seismic data processing, development of geophysical data management interface, interpolation of shot point data, trend surface analysis and Geostatistical analysis using GIS. Subsurface zones of high, low or null probability of petroleum accumulation were then, mapped. Finally, GIS based maps were developed. Geospatial tomography GIS model inferred that study area is structurally deformed and exhibits excessive geological faults, and structural traps. With GIS-tomography interpretation of section 97-MYL-08, a potential oil bearing zone (popup anticline), bounded by two thrust faults was observed at almost $3.6 \mathrm{Km}$ depth in Meyal area
\end{abstract}


with average density of about $2.6 \mathrm{gm} / \mathrm{cm}^{3}$. Thrust fault recognized from sharp discontinuity in GIS based survey raster was encountered at $2.9 \mathrm{Km}$ depth. Structure contour map was developed. It depicted that Chorgali formation (dolomitic limestone) at $3.68 \mathrm{Km}$ depth was proven to be reservoir rock in study area. GIS has proved to be a powerful and efficient subsurface modeling and analytical tool and it should be integrated with survey based studies for exploration of oil and gas and investigation of subsurface geological structures.

\section{Keywords}

Seismic Survey, Geographical Information System (GIS), Petroleum Reservoirs

\section{Introduction}

Pakistan's current yearly energy supply is equivalent to about 65.01 million tons of oil. Petroleum and natural gas fulfill about $78 \%$ of these requirements. Oil and gas are produced miles beneath the earth surface as a result of high pressure and temperature, induced on remains and fossils of dead animal, decayed and buried organic content and is a gradual process of thousands of years. Conventional petroleum exploration method used worldwide is reflected seismology and it involves heavy cost and machinery, and still, probability of hitting the extractable oil producing zone is low because of less accuracy or absence of required, analytical assessment techniques prior to drilling of well and difficulty of locating the promising zones of oil and gas. [1] explained that spatial 3D modeling of petroleum system is one of the highly informative and effective geo-tools for prediction of oil and gas accumulations in undrilled prospects. Development of 3D model of petroleum system of semi-regional scale requires a downscaling of geophysical, logging, geochemical, lithological and petrophysical data sets. Due to powerful analytical capabilities, Geographical Information System is capable of carrying out these surveys digitally and producing analytical maps to better understand the structures, trends and stratigraphy of deep earth. In this research work, an effort has been made to map and analyze subsurface geology for locating reservoirs of oil and gas using GIS to test its capabilities for potential subsurface structural investigations. [2] developed a multiplecriteria spatial decision support tool that identifies the potential degree of conflict associated with oil and gas production activities for existing lease tracts in the coastal margin of Texas. [3] stated that development of Geographical Information System (GIS) helped in representing and modeling earth's phenomena in an efficient way.

\section{Research Objectives}

Purpose of this research is Integration of Geographical Information System with Seismic Surveys for Structural and Stratigraphic Interpretation of Subsurface Geology and locating Petroleum Prospects. Study Area for research work is shown in Figure 1.

This research work has following objectives: 


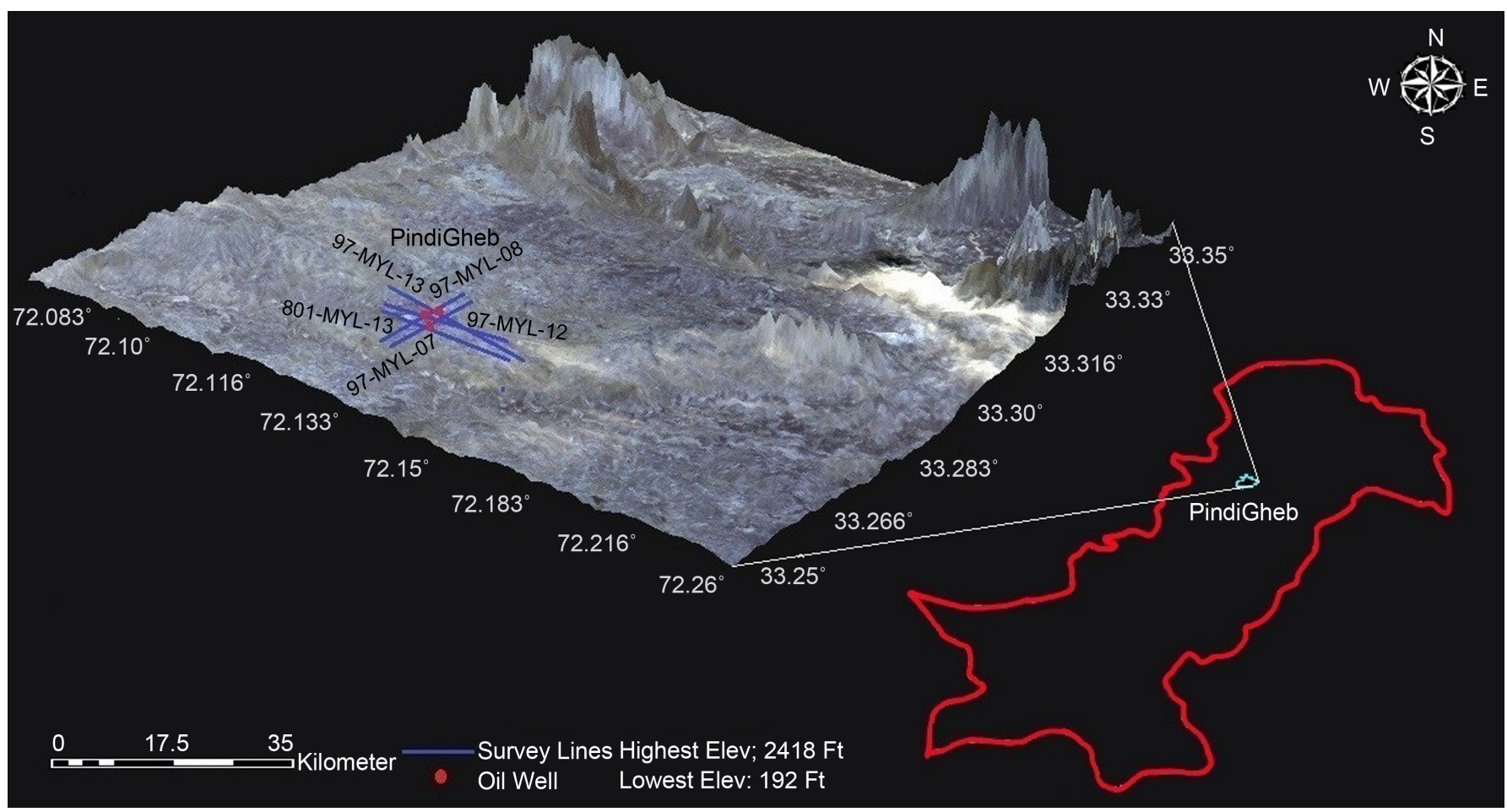

Figure 1. Location map of study area.

- Investigate subsurface Geological structures using GIS;

- Geostatistical analysis to locate petroleum reservoirs;

- Study trends of ${ }^{*}$ PHA zones and surfaces (spatial continuity) via Geoinformatics; *(PHA: Possible Hydrocarbon Accumulation zone).

\section{Methodology and Datasets}

Due to structurally deformed zones and high probability of hydrocarbon formation in the region, study area opted for this study is Meyal village, Potwar Plateau, upper Indus basin, Pakistan. Meyalvilllage is located in Tehsil PindiGheb, District Attock, Potwar plateau, 110 kilometers southwest of Islamabad in the active thrust belt of upper indus basin. Study area is bounded by extent Latitudes $33^{\circ} 13^{\prime} 0^{\prime \prime} \mathrm{N}-33^{\circ} 20^{\prime} 20^{\prime \prime} \mathrm{N}$ and Longitudes $72^{\circ} 4^{\prime} 0^{\prime \prime} \mathrm{E}-72^{\circ} 10^{\prime} 0 " \mathrm{E}$. [4] stated that the continued exploration efforts, application of the new technology and changing exploration methodology had resulted in the discovery of the Meyal Field. This is a very important message for explorationists. Three strike lines and two dip lines of Meyal area, Tehsil PindiGheb, District Attock were acquired from LandMark Resources (LMKR) Pvt. Ltd with prior approval from Directorate General Petroleum Concessions (DGPC), Islamabad, Pakistan, along with 03 Geophysical Logs: Gamma Ray Log, Resistivity Log and Density Log. 30 meter resolution Aster Digital Elevation Model (DEM) was acquired from United States Geological Survey (USGS). DEM was used to generate elevation model and contour map. [5] stated that first, geoscience information from various sources requires precise representation for spatial analysis. In many cases, the information to be represented is probabilistic or 
transient in nature, and it needs a mathematical tool that can adequately represent the information with a degree of possibility and/or uncertainty.

Methodological Framework designed for study is shown in Figure 2.

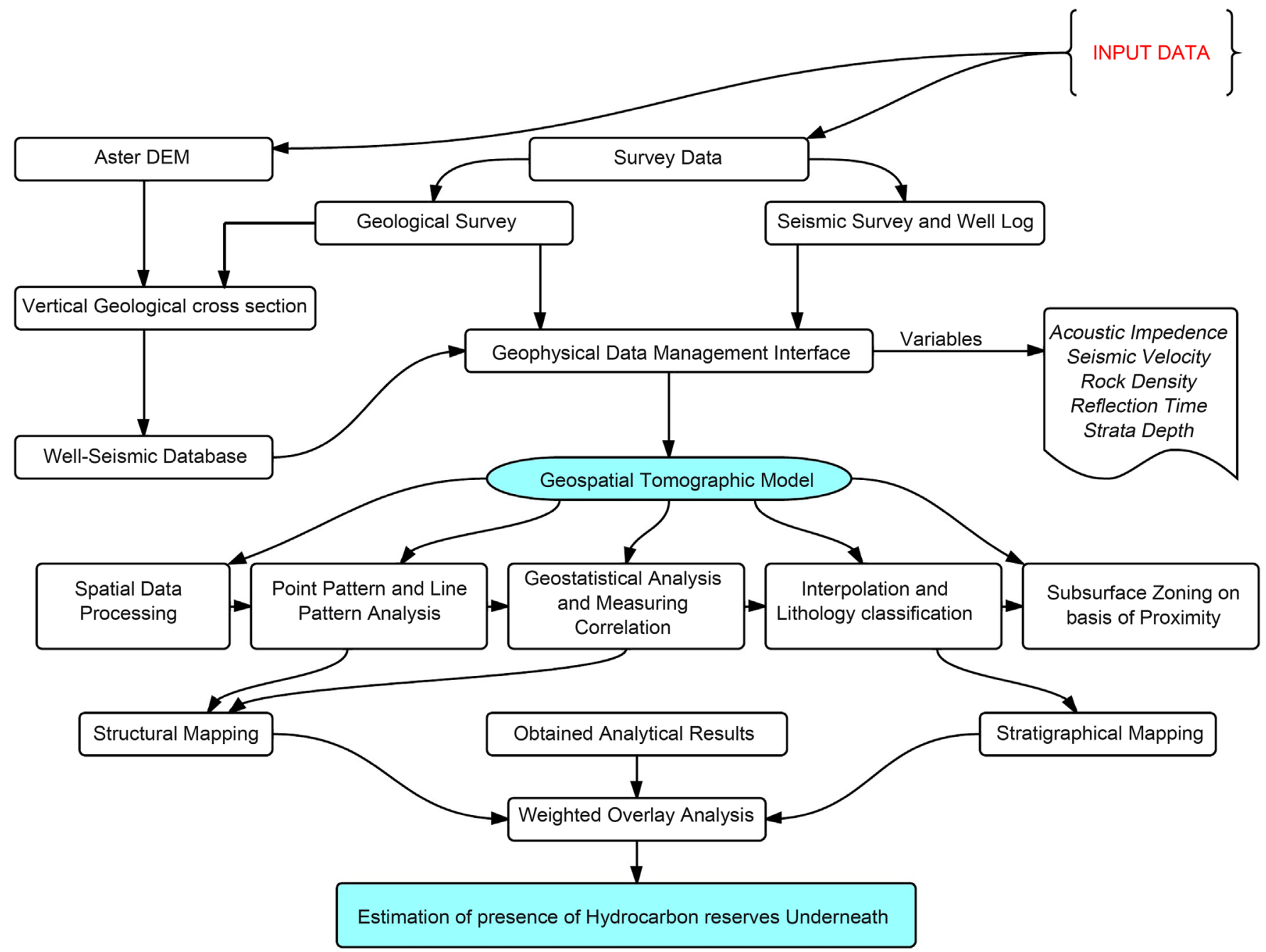

Figure 2. Methodological framework designed for study.

Well-seismic database was developed prior to processing of seismic parameters. Values of different parameters like seismic velocity, depth, reflection time, and rock bulk density (from density log) were the inputs in geospatial tomographic model (GSTM). Seismic velocity was inferred from velocity functions given on seismic sections. These are based on reflections from different type of subsurface lithology. Geophysical Data Management Interface stores this velocity for further analysis in GIS system. Then based on acoustic impedance $(z)$, strong reflectors are visually traced on sections and one way travel time, velocity and depth of these marked horizons are stored in database for further analysis.

$$
Z=v * ð
$$


(Z: Acoustic Impedance, v: Seismic Velocity, ð: Rock Density)

After calculation of Vint (Interval Velocity) and Vavg (Average Velocity) from velocity functions given on sections, Time sections are converted into depth section to infer depths of section using formula:

$$
S=V * T / 2000
$$

where

$$
\begin{aligned}
& S=\text { Depth in meters; } \\
& V=\text { Average Velocity in } \mathrm{m} \cdot \mathrm{s}^{-1} \\
& T=\text { Two way travel time in milliseconds. }
\end{aligned}
$$

Table 1 shows that the average recorded velocity of gas (at 1 atm and $25^{\circ} \mathrm{C}$ ) is 0.33 $\mathrm{km} / \mathrm{s}$ and for oil, it is $1.3 \mathrm{~km} / \mathrm{s}$. After development of well-seismic database, Inverse Distance Weighted (IDW) interpolation techniques were applied on seismic raster formulated in GIS system. This resulted in an interpolated surface of structures and stratigraphy, stratigraphy was recorded form well log data and correlated with GIS based interpolated surface. Kriging was also performed on seismic point data and results of both techniques were almost similar for subsurface geological mapping but IDW yielded best results for such type of structure based interpretations. Generated Seismic Grid is shown in Figure 3. Trend of surfaces and possible hydrocarbon accumulation zones were analyzed using trend surface analysis. Finally, a resultant seismic grid was generated using interpolation in GIS (where $Z=V s$ ) for further analysis. This includes velocity and depth values of whole section [6] explained that a three-dimensional model for Geographic Information System (GIS) visualization by ellipsoid-based digital terrain model (DTM) is suggested for the first time. In this model spatial objects are classified as types of point, line, surface attached to terrain, body objects. By overlapping spatial phenomenon with ellipsoid-based DTM, these models of spatial entities, such as road model, rive model, lake model and building model are achieved and demonstrated in $3 \mathrm{D}$ visualization.

Table 1. Density and velocity of different materials (Source: Sydney P. Clark, Jr. (ed.), "Handbook of Physical Constants", 1996).

\begin{tabular}{ccc}
\hline Material & Average Density $\left(\mathrm{gm} / \mathrm{cm}^{3}\right)$ & Average velocity $(\mathrm{km} / \mathrm{s})$ \\
\hline Limestone & $1.93-2.90$ & 6.4 \\
Dolomite & $2.28-2.90$ & 7.0 \\
Sandstone & $1.61-2.76$ & 5.5 \\
Shale & $1.77-3.4$ & 3.4 \\
Oil & $0.6-0.8$ & 1.3 \\
Gas (at 1 atm and $\left.25^{\circ} \mathrm{C}\right)$ & 0.0008 & 0.33 \\
Water & 1.000 & 1.5 \\
\hline
\end{tabular}




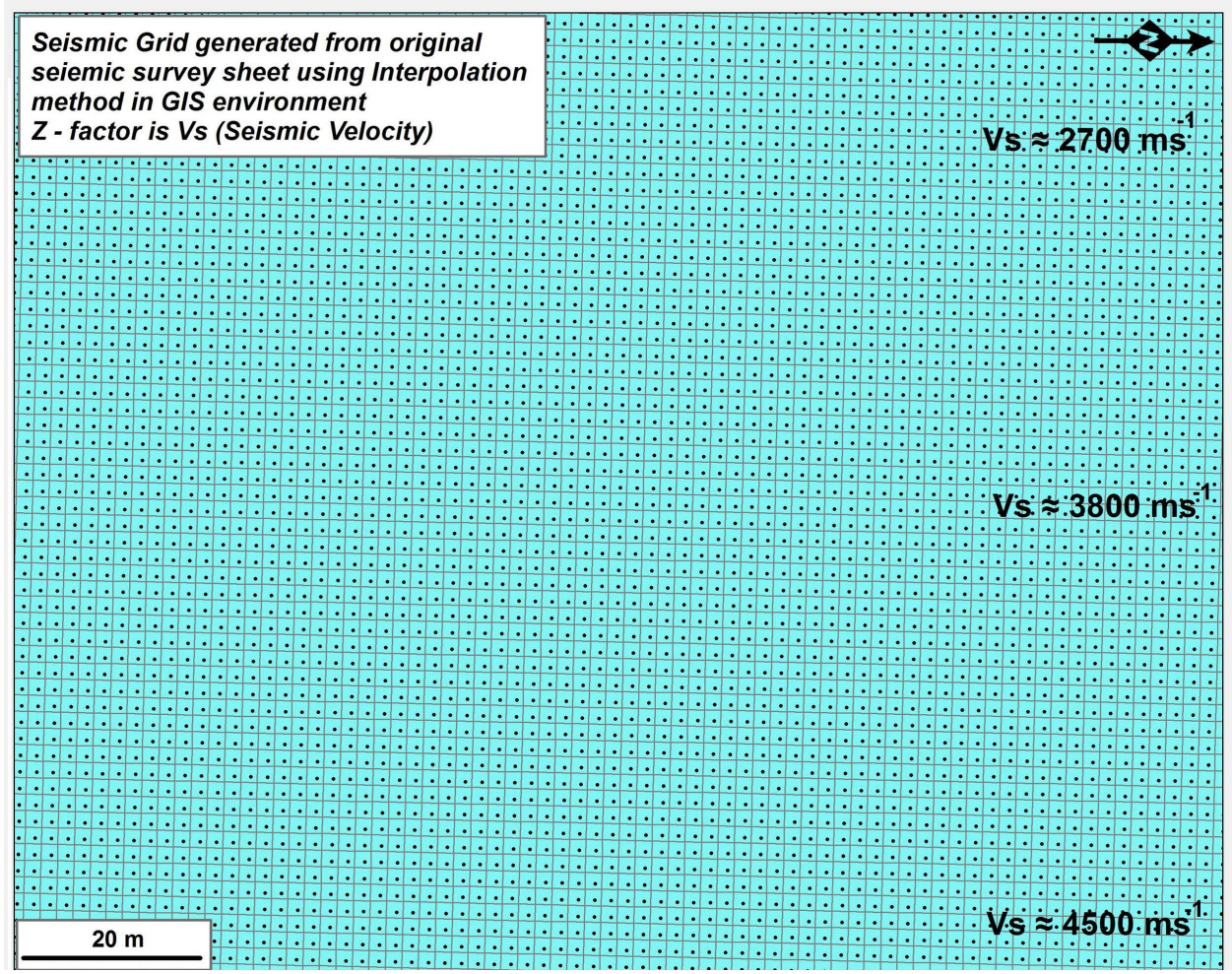

Figure 3. Seismic grid generated using GIS analytical techniques.

\section{Results}

GIS was used to interpret seismic section using geostatistical analysis and trend surface analysis. It was observed that Meyal lies in active thrust belt or compressional regime dominated by anticlines, study area is structurally deformed and exhibits excessive structural traps hence oil and gas bearing zones. At $3.4 \mathrm{~km}$ depth, a popup structure, anticline has been encountered bounded by thrust faults dipping inward at dip line 97myl08 delineated using Geostatistical analysis, trend surface analysis, borehole tools and $\mathrm{x}$-tools. This is first Possible Hydrocarbon Accumulation (PHA) zone encountered. Results have been shown in Figure 4 and Figure 5.

Geologically, anticlinal structures are favorable geological structures for petroleum accumulation. With corresponding well log correlation, it was inferred that deformed structure generated in raster is Chorgali formation (Dolomitic Limestone) of Eocene geological age which is proven reservoir rock of Meyal area. Studies by [7] suggested that the probability maps can be used as input data in exploration risk assessment and as constraints in reservoir modeling and performance forecasting.

\section{Seismic Velocity and 3D Reservoir Modelling}

Velocity recorded in seismic survey is P-wave or compressional velocity recorded as rock or strata reflection. Seismic Velocity Modeling is an approach of interactive computation enabling velocity model building and the execution of depth imaging workflows in a 3D visualized environment. Seismic Velocity is very important parameter for 


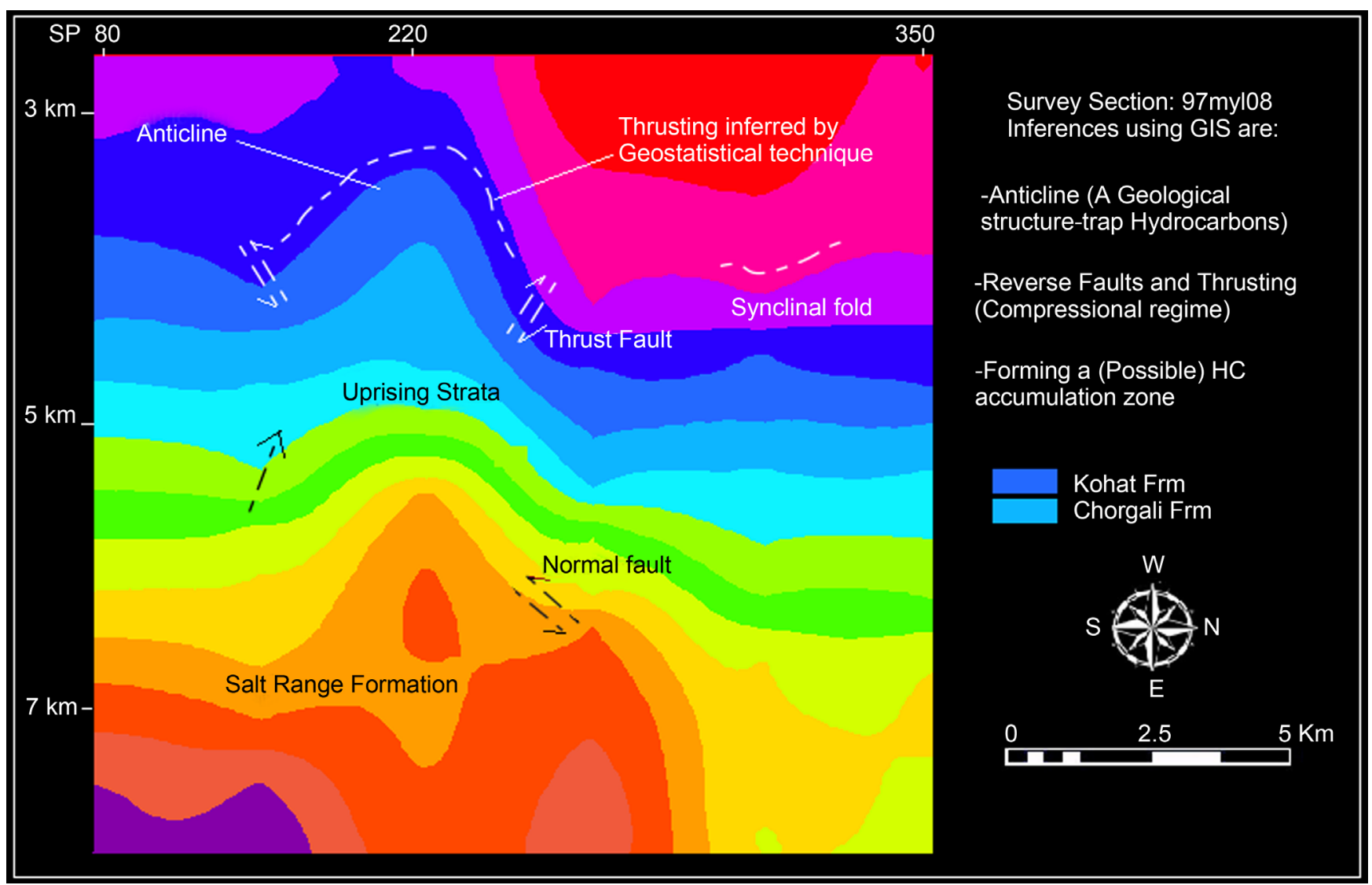

Figure 4. GIS based structural interpretation of survey section 97-MYL-08.

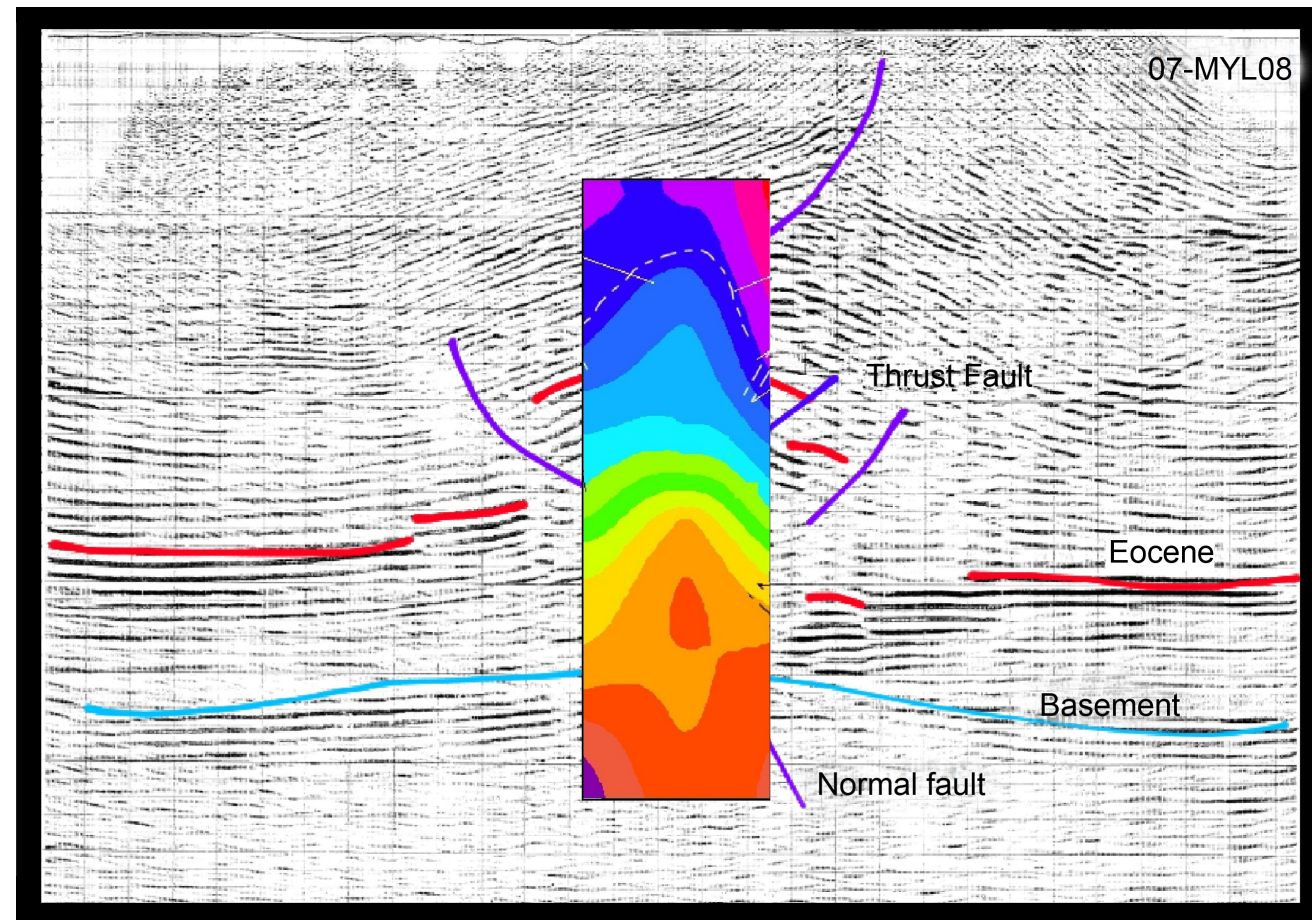

Survey Section: 97 myl08 Inferences using GIS are:

-Anticline (A Geological structure-trap Hydrocarbons)

-Reverse Faults and Thrusting (Compressional regime)

-Forming a (Possible) HC accumulation zone

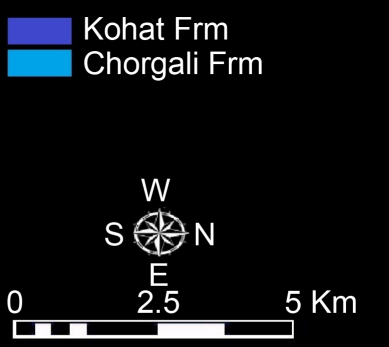

Figure 5. GIS based section 97-MYL-08 overlain on original seismic sheet to correlate structures. 
subsurface structure delineation, GIS was used to model surface on basis of velocity as z factor. 3D reservoir model was produced as a result of surface interpolations in ArcScene 10.1. as shown in Figure 6.

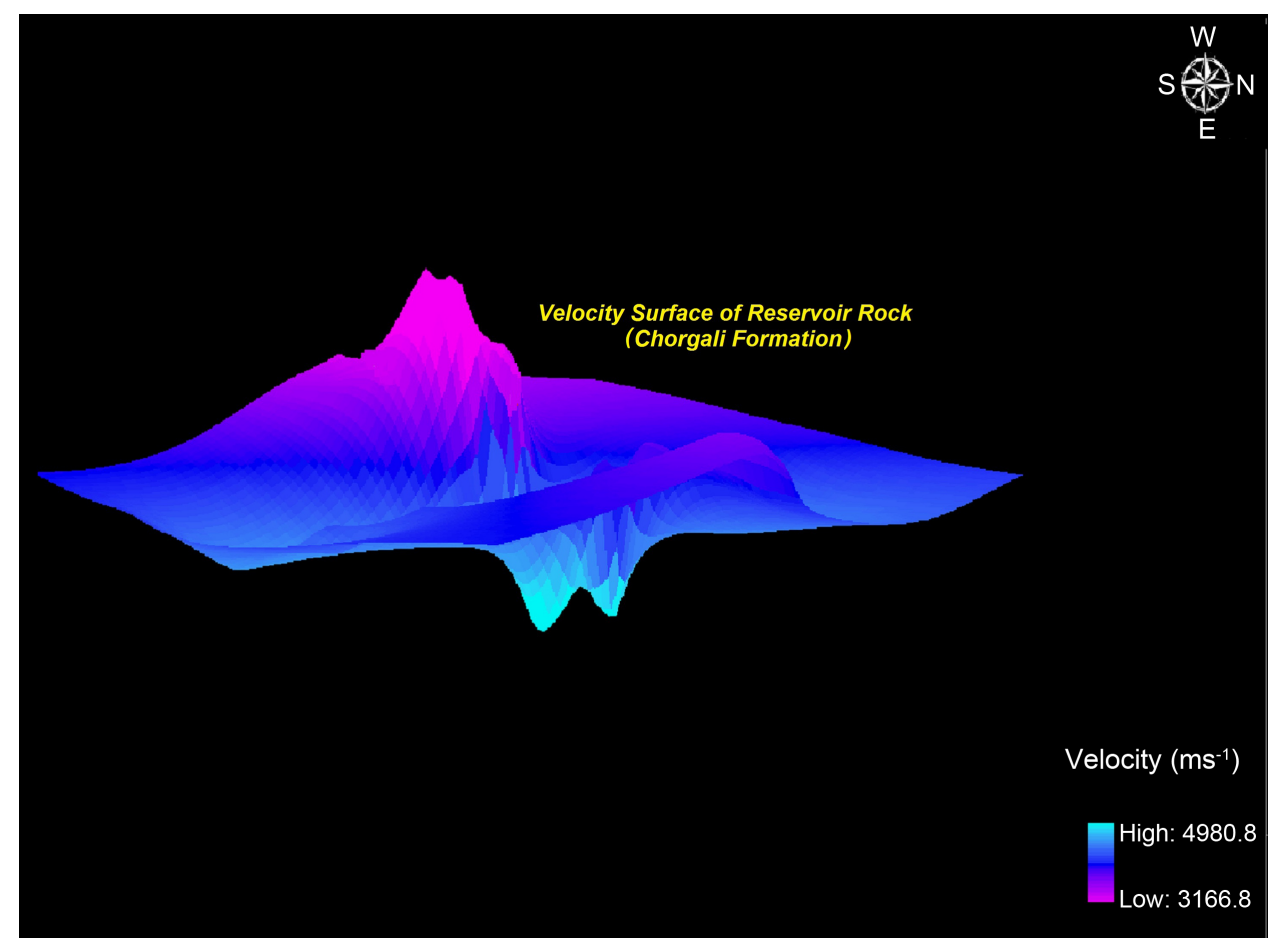

Figure 6. Modelling the reservoir rock using GIS.

On the basis of structure contour mapping, reservoir rock and main lithologies are identified. 3D models of these lithologies are then generated in GIS. Reservoir rock is modeled using parameters such as seismic velocity, strata depth, bulk density and reflection time of that particular reflector. In study area, reservoir rock is Chorgali formation of Eocene age. Oil and natural gas are stored through migration in porous and permeable rocks called reservoir rock in which these liquids have accumulated throughout the vast expanse of geological era, stored under seal rocks or traps. Modeling the reservoir rock is most important step in exploration because well is drilled directly on reservoir rock. Reservoir rock is porous and permeable rock and using GIS analysis, it was inferred that first structural deformation that was observed, was reservoir rock. A popup anticline bounded by two thrust fault has been encountered at almost 3681 meter depth. Manual interpretation of seismic section for cross verification, 97-MYL-08 is shown in Figure 7.

General trends of velocity change with respect to depth are plotted below. Change in values has been plotted at individual Common Depth Point (CDP) for survey section 97-MYL-08 (Figure 8).

[8] stated that to improve the geologic model and test the approach, high-resolution seismic reflection methods were used in a re-evaluation study of earthquake hazard assessment at the Krško nuclear power plant (NPP) site. 


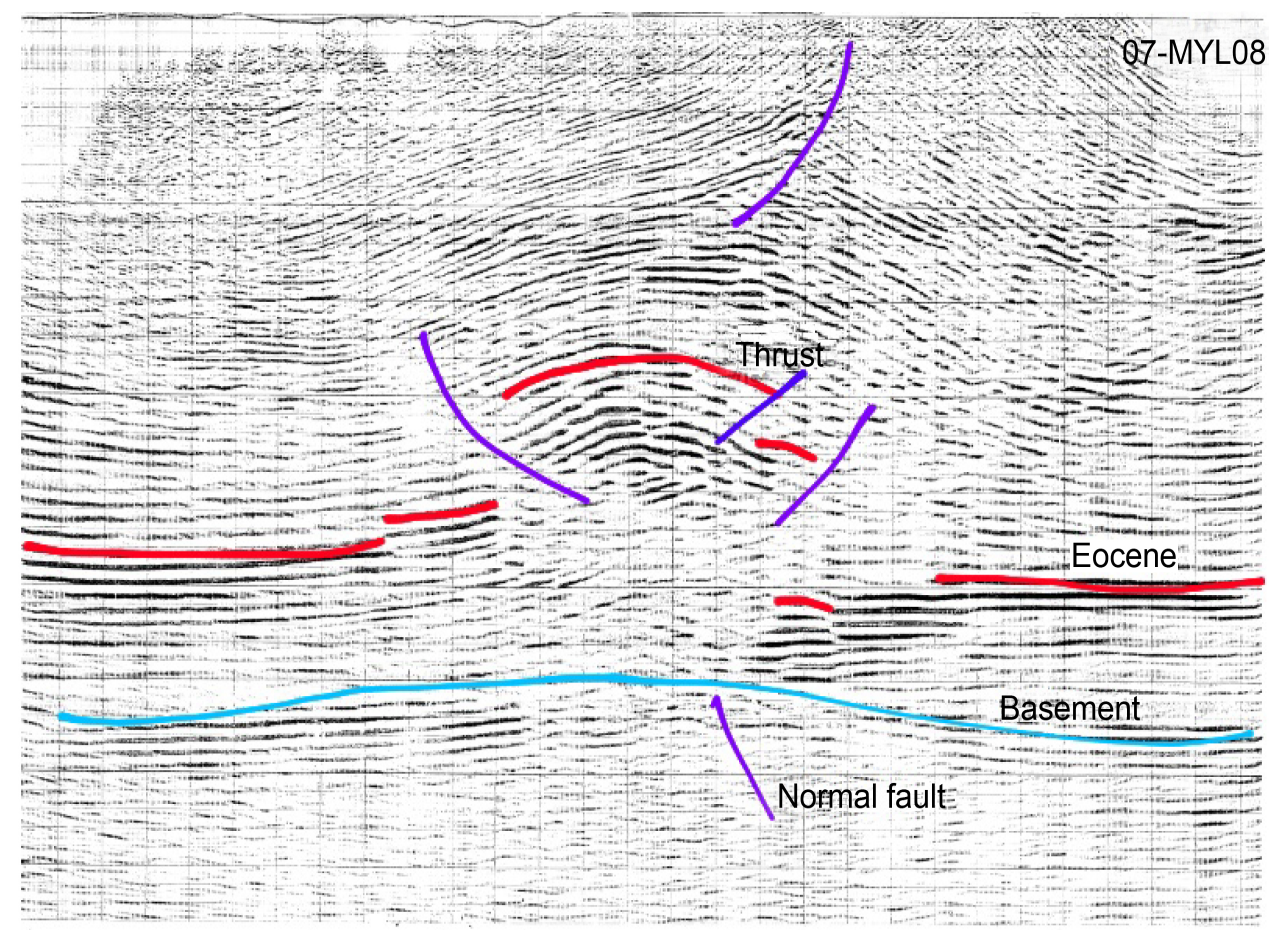

Figure 7. Manual interpretation of section 97-MYL-08.

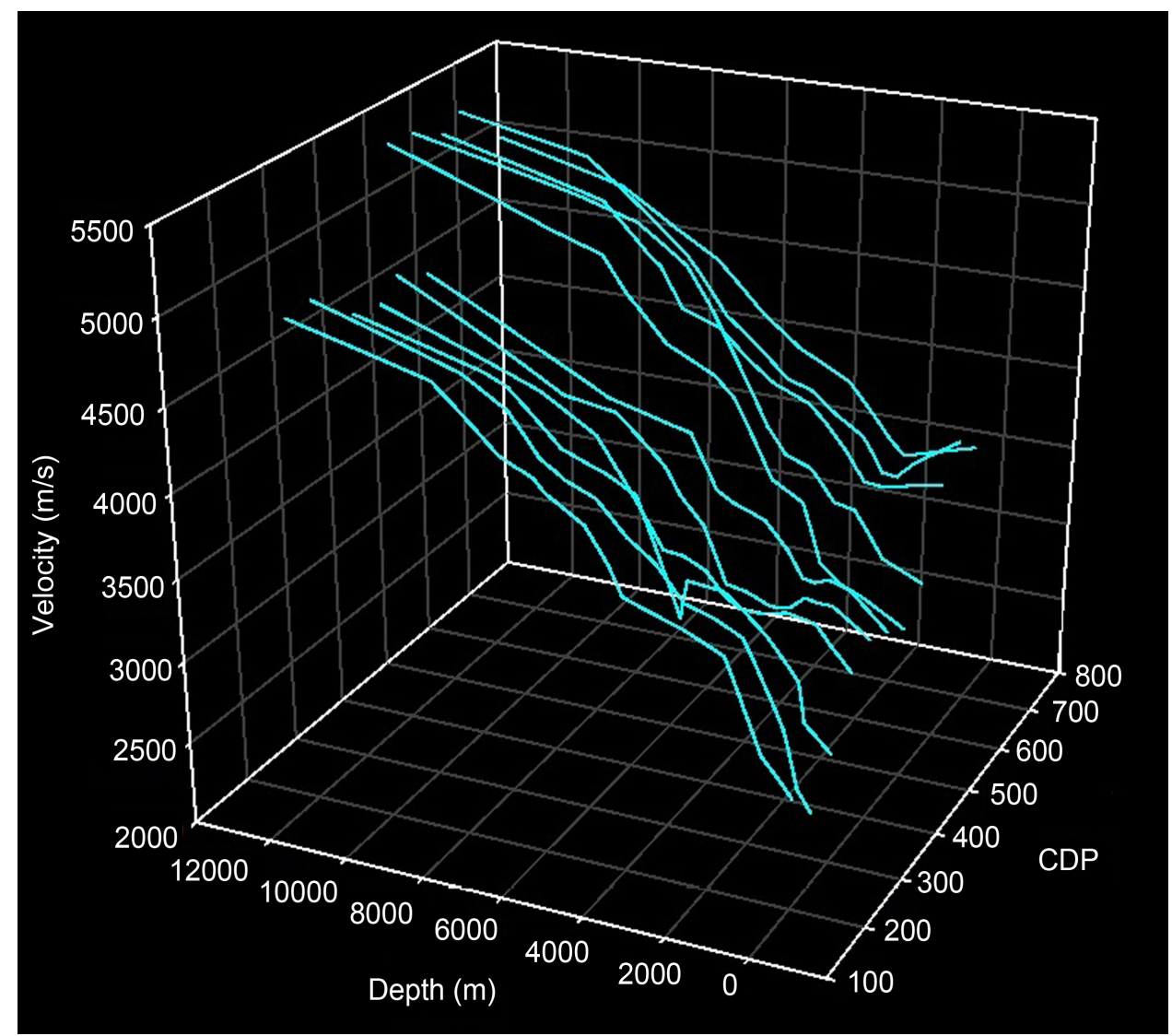

Figure 8. Depth vs. velocity plot 97-MYL-08. 


\section{Conclusion and Recommendation}

Petroleum Exploration requires the analysis of a lot of different types of data such as satellite imagery, seismic surveys, surface geological studies, subsurface studies, cross section, well logs, and existing infrastructure information. GIS serves as an excellent analytical tool for such purposes. Geophysical processing software usually lacks GIS functionality. GIS should be integrated with seismic surveying techniques to achieve more accuracy and powerful analytical results. [9] stated that the Kufrah Basin was mapped through the integration of Radarsat, SRTM and Landsat. With GIS-Tomography integration, a potential oil bearing zone was hit at $3.4 \mathrm{~km}$ depth in Meyalarea. GIS is an excellent and powerful analytical tool for subsurface investigations and study trends of different surface and subsurface models. GIS can generate potential models and analytical maps that can be integrated with geological and geophysical models to better understand and visualize structures and stratigraphy. GIS should be integrated with seismic surveying to achieve maximum accuracy and powerful analysis. GIS is capable of surface and subsurface geological contouring and modeling. [10] stated that Geoinformatics is a fledgling effort, yet significant efforts are underway around the world that could make it as powerful and important to the geosciences as bioinformatics has become to the pharmaceutical and bioengineering communities. The societal demands that will drive the development of Geoinformatics are resource exploitation, environmental preservation and restoration, water needs, and geologic hazards response and mitigation.

\section{Acknowledgements}

We wish to thank Landmark Resources (LMKR) Pvt Ltd., Islamabad, Pakistan for continuous guidance, monitoring and support during this research work. IGIS, NUST University Islamabad, is acknowledged for providing adequate research funds, laboratory and library facility for the completion of this research work.

\section{References}

[1] Avseth, P., Mukerji, T., et al. (2001) Seismic Reservoir Mapping from 3-D AVO in a North Sea Turbidite System. Geophysics, 66, 1157-1176.

[2] Brody, S.D., Grover, H., et al. (2006) Identifying Potential Conflict Associated with Oil and Gas Exploration in Texas State Coastal Waters: A Multicriteria Spatial Analysis. Environmental Management, 38, 597-617.

[3] Anbazhagan, S., Subramanian, S.K. and Yang, X.J. (2011) Geoinformatics in Applied Geomorphology. CRC Press Book, Boca Raton.

[4] Hasany, S.T. and Saleem, U. (2012) An Integrated Subsurface Geological and Engineering Study of Meyal Field. Potwar Plateau, Pakistan. Search and Discovery Article, 2015, 1-41.

[5] Chen, Z.H., Embry, A.F., et al. (2002) Hydrocarbon Favourability Mapping Using Fuzzy Integration: Western Sverdrup Basin, Canada. Bulletin of Canadian Petroleum Geology, 50, 492-506.

[6] Yan, F. and Shi, Y.-M. (2004) Three-Dimensional Geographic Information System Visuali- 
zation Model Depended on Ellipsoid-Based Digital Terrain Model. Journal of Tongii University, 32, 1192-1196.

[7] Karpenko, I. (2016) Identification of Petroleum System Elements and Downscaling of Complex Geo-Data Sets for Development of 3D Model of Semi-Regional Scale. Example of Southern Border Area of Dnieper-Donets Rift. 15th EAGE International Conference on Geoinformatics-Theoretical and Applied Aspects, 10 May 2016.

[8] Gosar, A. (1998) Seismic Reflection Surveys of the Krsko Basin Structure: Implications for Earthquake Hazard at the Krsko Nuclear Power Plant, Southeast Slovenia. Journal of Applied Geophysics, 39, 131-153.

[9] Ghoneim, E., Benedetti, M. and El-Baz, F. (2012) An Integrated Remote Sensing and GIS Analysis of the Kufrah Paleoriver, Eastern Sahara. Geomorphology, 139-140, 242-257.

[10] Allison, M.L. (2001) The Geoinformatics Model-Examples of a Spatially Based System for the Earth Sciences. GSA Annual Meeting, Boston, 5-8 November 2001.

Submit or recommend next manuscript to SCIRP and we will provide best service for you:

Accepting pre-submission inquiries through Email, Facebook, LinkedIn, Twitter, etc.

A wide selection of journals (inclusive of 9 subjects, more than 200 journals)

Providing 24-hour high-quality service

User-friendly online submission system

Fair and swift peer-review system

Efficient typesetting and proofreading procedure

Display of the result of downloads and visits, as well as the number of cited articles

Maximum dissemination of your research work

Submit your manuscript at: http://papersubmission.scirp.org/

Or contact ijg@scirp.org 